\section{Roadside grassland vegetation in an oak forest, Oak Creek Wildlife Area, the Cascade Range, USA}

\begin{abstract}
Tsuyuzaki S ${ }^{(1)}$, Titus $\mathrm{JH}^{(2)}$
Roadside grassland vegetation in a Quercus garryana forest, that is one of the dominant species in west Cascade, on the Oak Creek Wildlife Area, Naches, Washington, USA, was investigated to determine the patterns of human impact on the vegetation along mountain trails. Vegetation and environmental data were collected on forty-eight $50 \mathrm{~cm} \times 50 \mathrm{~cm}$ plots. Plot cover ranged from 3 to $100 \%$ ( 1 to 8 species) and most of the cover was from exotic species. In order to explore vegetation patterns the following environmental variables were measured: slope, tree canopy area, bare area, distance from road, and litter thickness. The vegetation data and environmental variables were examined using Canonical Correspondence Analysis (CCA). CCA showed that canopy area played important roles in vegetation development. Litter thickness and soil firmness also seemed to be related to the vegetation pattern. Distance from the road affected plant cover but was not related to canopy area, and litter thickness, suggesting that the distance was not a prime determinant on the vegetation pattern a priori. Species richness was the highest in mid-vegetation cover plots, i.e., 40-60\%. An exotic plant, Sisymbrium officinale, increased in frequency with a decrease in vegetation cover, and two exotic plant species, Achillea millefolium and Anthoxanthum odoratum, occurred with S. officinale. $S$. officinale may be a good indicator for evaluating environmental deterioration. The preservation of canopy cover is of prime importance for nature conservation in forested recreational areas.
\end{abstract}

Keywords: Canonical Correspondence Analysis (CCA), Oak forest, Roadside, Litter thickness, Species indicator

\section{Introduction}

Human impacts strongly control vegetation development patterns, in particular, in mountainous regions, due to tourists (Myers \& Bazely 2003, Turton 2005). Roads, including mountain trails, are convenient corridors for the movement of non-native species via human activities (Trombulak \& Frissell 2000, Thiele \& Otte 2008). As a result of human impacts, roadside grassland vegetation decreases in cover, and native herbaceous plants are excluded by exotic ones (Goudie 2005).

(1) Graduate School of Environmental Earth Science, Hokkaido University, Sapporo 060-0810 (Japan); (2) Biology Department at SUNY Fredonia, NY 14063 (USA)

(a) Shiro Tsuyuzaki

(tsuyu@ees.hokudai.ac.jp)

Received: Nov 05, 2009 - Accepted: Dec 29, 2009

Citation: Tsuyuzaki S, Titus JH, 2010. Roadside grassland vegetation in an oak forest, Oak Creek Wildlife Area, the Cascade Range, USA. iForest 3: 52-55 [online: 201003-02] URL: http://www.sisef.it/iforest/ doi.php?doi $=10.3832 /$ ifor0527-003
Quercus garryana Douglas ex Hook. is distributed in the Cascade Range from California, USA, to British Columbia, Canada, and is often dominant in the mountainous regions (Thilenius 1968, Thysell \& Carey 2001). In the western USA, oak forests have been widely utilized as recreation areas (Riegel et al. 1992, Thysell \& Carey 2001), and exotic herbaceous plants have dramatically increased along roads and campgrounds in those parks. The effect of human impacts on oak forest grassland vegetation should be monitored to conserve and restore the natural vegetation of those recreational areas.

To conserve understory vegetation in forests, environmental determinants on plant distribution patterns should be clarified. However, environmental factors interact such that the factors that influence the vegetation are complex (Walker \& Chapin III 1987). Bare area is used as an indicator for environmental deterioration (Watkins et al. 2003, Labuz \& Grunewald 2007). In particular, environmental factors on ground layer are influenced by the upper layers, such as canopy. Therefore, the distribution pattern of canopy layer should be mentioned, because the pattern might be modified by road construction. Based on these consideration, we conducted: 1) finding out grassland vegetation establishment patterns along a cover gradient, 2) detecting the environment-species relationships, and 3) seeking indicator species and environmental factors that illustrate the development of roadside grassland vegetation.

\section{Study area and methods}

The survey area was located within the Oak Creek Wildlife Area, about $70 \mathrm{~km}$ east from Mt. Rainer (4392 m a.s.1.) on the Cascade Range near Naches, Washington, USA $\left(46^{\circ} 43^{\prime} \mathrm{N}, 120^{\circ} 48^{\prime} \mathrm{W}, 530 \mathrm{~m}\right.$ a.s.l.), which is managed by the State of Washington Department of Fish and Wildlife. Number of visitors was 80000 to 100000 per year around 1990 and increased to 129000 in 2004. The forest canopy was dominated by Quercus garryana (Oregon white oak), Pseudotsuga menziesii (Douglas-fir), and Acer macrophyllum (bigleaf maple). Q. garryana is distributed widely in the Cascade Range from British Columbia, Canada, to California, USA (Thilenius 1968). In Oak Creek Wildlife Area, trees were 10 to $20 \mathrm{~m}$ in height, and were sparsely distributed. So far, logging and seeding have been performed as needed. Although 2 000-3 000 elk (Cervus canadensis Erxleben nelsoni Batley) live in the wildlife area, grazing does not modify vegetation (Rexroad et al. 2007). In Yakima (46 $\left.34^{\prime} \mathrm{N}, 120^{\circ} 32^{\prime} \mathrm{E}\right)$, mean annual temperature is ca. $10^{\circ} \mathrm{C}$, and mean annual rainfall is $205 \mathrm{~mm}$ (NCDC 1993). At Oak Creek, dirt trails and roads are constructed and road width is usually $4 \mathrm{~m}$.

To detect plant establishment patterns along disturbance gradients, in particular, when bare ground is developed, plot cover classes are often used (Sauer \& Ries 2008, Moreno-de las Heras et al. 2009). In this study, plot cover was classified into 3 categories: 1 : $0 \%-40 \% ; 2$ : $40 \%-60 \%$; and 3 : $60-100 \%$. In each category, sixteen $0.5 \times 0.5$ $\mathrm{m}^{2}$ plots were randomly set up in the summer of 1993. Percent cover of each vascular plant species was visually estimated in each plot divided into twenty-five $10 \mathrm{~cm} \times 10 \mathrm{~cm}$ cells. In each plot cover class, percent frequency for each species was calculated. Distance from the roadside, litter thickness and percent canopy cover were determined for each plot. Percent tree canopy (more than 2 $\mathrm{m}$ high) cover was visually estimated in a 5 $\times 5 \mathrm{~m}$ area above each plot. Distance, litter thickness and slope were measured on the center of each plot by a tape, ruler and clinometer.

The differences of environmental factors, plot cover and species richness between the cover categories were analyzed by Scheffe's test (Zar 1999). Based on each species cover in each plot, niche breadth and overlap for 
each species were calculated according to Colwell \& Futuyma 1971. Niche breadth and overlap range from 0 to 1 . Niche breadth evaluates habitat preference, while niche overlap indicates the similarity of habitat preferences between two species. Environment-species and environment-plot relationships were investigated by Canonical Correspondence Analysis, in order to simplify the analysis of species-environment relationships in a technique analogous to linear regression (Leps \& Šmilauer 2003). The nature of the relationships can be shown in an ordination diagram by vectors with lengths proportional to their importance and directions showing their correlations with each axis. The $t$-values of environmental variables can be compared with the Student $t$-distribution, i.e., a variable contributes significantly to the regression when it exceeds the critical value. Species and samples are plotted in the ordination diagram such that major relationships can be directly observed. Species matrices were composed of percent cover for species with more than two occurrences. The hypothesis of non-significant variation from that explained by a random variable was tested by the Monte Carlo test with 499 unrestricted permutations of the constraining variable.

\section{Results}

Distance from the road varied from $0.0 \mathrm{~m}$ to $13.0 \mathrm{~m}$ (Tab. 1). Slope ranged from $0^{\circ}$ to $27^{\circ}$, and steep slopes had low plot cover. Steep sites were distributed more on areas closer to road. Litter thickness ranged from $0.0 \mathrm{~cm}$ to $5.5 \mathrm{~cm}$, and did not differ between cover categories. This implied that litter thickness is variable in each cover class. Tree canopy cover varied greatly from $0 \%$ to $80 \%$, and there were no significant differences between cover categories.

There were 31 vascular plants in the surveyed plots. Vegetation was $50 \mathrm{~cm}$ high on average. There were not great differences in species composition among cover categories, although plot cover varied from 3 to $100 \%$. Ten species were exotics, and the common exotics were Sisymbrium officinale L., Anthoxanthum odoratum L., and Achillea millefolium L. (Tab. 1). S. officinale occurred in most plots, and Poa nervosa (Hook.) Vasey, A. odoratum and A. millefolium were also common. Those four species had a frequency greater than $40 \%$. Of those four species, only $P$. nervosa was native. No other species had a frequency less than $20 \%$. On exotic species, Sisymbrium officinale was widespread, but decreased in frequency with an increase in plot cover. In contrast, Achillea millefolium, Festuca elatior L. increased in frequency with increased plot cover. P. nervosa and Elymus cinereus (Schrib. Et Merr.) Love, two native species, decreased in frequency and cover in plots

Tab. 1 - Mean environmental factors ( \pm S.D.) and plant cover by species (with percentage appearance frequencies) for three cover categories. The same letters aside the mean values indicate non-significantly different values at $\mathrm{P}>0.05$ (Scheffe's test); $\left.{ }^{*}\right)$ : exotic species.

\begin{tabular}{|c|c|c|c|c|}
\hline Cover category (\%) & $>60$ & $60>>40$ & $40>$ & Total \\
\hline Slope gradient (o) & $2.6^{\mathrm{a}} \pm 4.7$ & $1.3^{\mathrm{a}} \pm 2.0$ & $12.3^{b} \pm 9.7$ & $\begin{array}{l}5.4 \pm 8.0 \\
(27.0-0.0)\end{array}$ \\
\hline Litter thickness $(\mathrm{cm})$ & $1.6^{\mathrm{a}} \pm 1.3$ & $0.8^{\mathrm{a}} \pm 0.9$ & $0.7^{\mathrm{a}} \pm 1.5$ & $\begin{array}{c}1.0 \pm 1.3 \\
(0.0-5.5)\end{array}$ \\
\hline Tree canopy area (\%) & $21.1^{\mathrm{a}} \pm 22.2$ & $10.8^{a} \pm 13.9$ & $17.2^{\mathrm{a}} \pm 23.0$ & $\begin{array}{c}16.4 \pm 20.6 \\
(80.0-0.0)\end{array}$ \\
\hline Distance from road $(\mathrm{m})$ & $3.2^{\mathrm{a}} \pm 3.0$ & $4.7^{\mathrm{a}} \pm 4.4$ & $0.6^{\mathrm{b}} \pm 1.1$ & $\begin{array}{c}2.8 \pm 3.6 \\
(13.0-0.0)\end{array}$ \\
\hline
\end{tabular}

\begin{tabular}{lcccc}
\hline \multicolumn{1}{c}{ Species } & & & & \\
Sisymbrium officinale (L.) Scop. ${ }^{*}$ & 23.3 & 19.0 & 8.2 & $16.8 \pm 20.2$ \\
& $(69)$ & $(81)$ & $(94)$ & $(73)$ \\
Poa nervosa (Hook.) Vasey & 7.2 & 8.0 & 2.7 & $5.9 \pm 11.2$ \\
& $(50)$ & $(63)$ & $(38)$ & $(50)$ \\
Anthoxanthum odoratum L.* & 4.9 & 2.3 & 0.9 & $2.7 \pm 5.6$ \\
& $(44)$ & $(69)$ & $(25)$ & $(46)$ \\
Achillea millefolium L. $^{*}$ & 5.1 & 2.7 & 0.4 & $2.7 \pm 6.7$ \\
Festuca elatio L.* & $(56)$ & $(50)$ & $(13)$ & $(40)$ \\
& 20.0 & 3.3 & 0.0 & $7.8 \pm 20.6$ \\
Elymus cinereus (Scrib. et Merr.) & $(32)$ & $(19)$ & $(0)$ & $(17)$ \\
Love & 6.6 & 1.9 & 0.6 & $3.0 \pm 10.7$ \\
Lepidium virginicum L. ${ }^{*}$ & $(25)$ & $(13)$ & $(6)$ & $(15)$ \\
& 3.8 & 4.1 & 0.6 & $2.8 \pm 10.6$ \\
Lolium perenne L.* & $(13)$ & $(19)$ & $(13)$ & $(15)$ \\
Melica spectabilis Scribn. & 0.9 & 3.4 & 0.0 & $1.5 \pm 5.6$ \\
Bare area (\%) & $(6)$ & $(25)$ & $(0)$ & $(10)$ \\
Mean species richness & 0.0 & 1.0 & 0.1 & $0.4 \pm 2.1$ \\
& $(0)$ & $(19)$ & $(13)$ & $(10)$ \\
& $22.8^{\mathrm{a}} \pm 12.3$ & $50.2^{\mathrm{b}} \pm 6.6$ & $79.6^{\mathrm{c}} \pm 12.6$ & $50.9 \pm 25.7$ \\
& & & & $(0-97)$ \\
& $3.5^{\mathrm{ab}} \pm 1.3$ & $4.5^{\mathrm{b}} \pm 1.4$ & $2.9^{\mathrm{a}} \pm 1.5$ & $3.6 \pm 1.5$ \\
& & & & $(8-1)$ \\
\hline
\end{tabular}

with less than $40 \%$ in cover. Species richness was highest in mid-cover plots (category $2=40 \%-60 \%$ in cover), and was the lowest in low-cover plots.

$S$. officinale showed the highest niche breadth (Tab. 2). Three exotic species, S. officinale, A. odoratum and A. millefolium, showed high niche overlaps with each other,

Tab. 2 - Niche breadth and overlap on common species. Species abbreviations are shown in parentheses and are also used in Fig. 1.

\begin{tabular}{|c|c|c|c|c|c|c|c|c|c|}
\hline \multirow{2}{*}{ Species } & \multirow{2}{*}{$\begin{array}{c}\text { Niche } \\
\text { breadth }\end{array}$} & \multicolumn{8}{|c|}{ Species abbreviation } \\
\hline & & SO & PN & AO & $\mathbf{A M}$ & FE & EC & $\mathbf{L V}$ & $\mathbf{L P}$ \\
\hline Sisymbrium officinale (SO) & 0.33 & - & - & - & - & - & - & - & - \\
\hline Poa nervosa $(\mathrm{PN})$ & 0.23 & 0.29 & - & - & - & - & - & - & - \\
\hline Anthoxanthum odoratum (AO) & 0.19 & 0.59 & 0.22 & - & - & - & - & - & - \\
\hline Achillea millefolium (AM) & 0.16 & 0.53 & 0.36 & 0.68 & - & - & - & - & - \\
\hline Festuca elatior $(\mathrm{FE})$ & 0.19 & 0.04 & 0.05 & 0.23 & 0.19 & - & - & - & - \\
\hline Elymus cinereus (EC) & 0.10 & 0.15 & 0.14 & 0.06 & 0.10 & 0.08 & - & - & - \\
\hline Lepidium virginicum (LV) & 0.10 & 0.14 & 0.01 & 0.08 & 0.00 & 0.00 & 0.00 & - & - \\
\hline Lolium perenne (LP) & 0.06 & 0.19 & 0.10 & 0.22 & 0.17 & 0.01 & 0.00 & 0.00 & - \\
\hline Melica spectabilis (MS) & 0.03 & 0.04 & 0.23 & 0.02 & 0.11 & 0.05 & 0.06 & 0.00 & 0.02 \\
\hline
\end{tabular}

i.e., more than 0.53 . The niche overlaps of other species were less than 0.36 . On native species, Poa nervosa established with those three exotic species. However, Melica spectabilis Scribn. showed less than 0.11 niche overlaps with any other common species, except 0.23 overlap with $P$. nervosa that is native. 
Fig. 1 - CCA ordination triplot diagram of the first two axes in relation to cover categories. Closed circles show species scores. Open triangles, squares and circles indicate plot scores of cover categories $1(0 \%-40 \%), 2(40-60 \%)$ and $3(60 \%$ $100 \%$ ), respectively. Environmental variables:

BARE $=$ bare area on the ground surface; CANP = tree canopy area; DIST $=$ Distance from road; SLOP $=$ slope THCK $=$ litter thickness. Species codes are shown in Tab. 2.

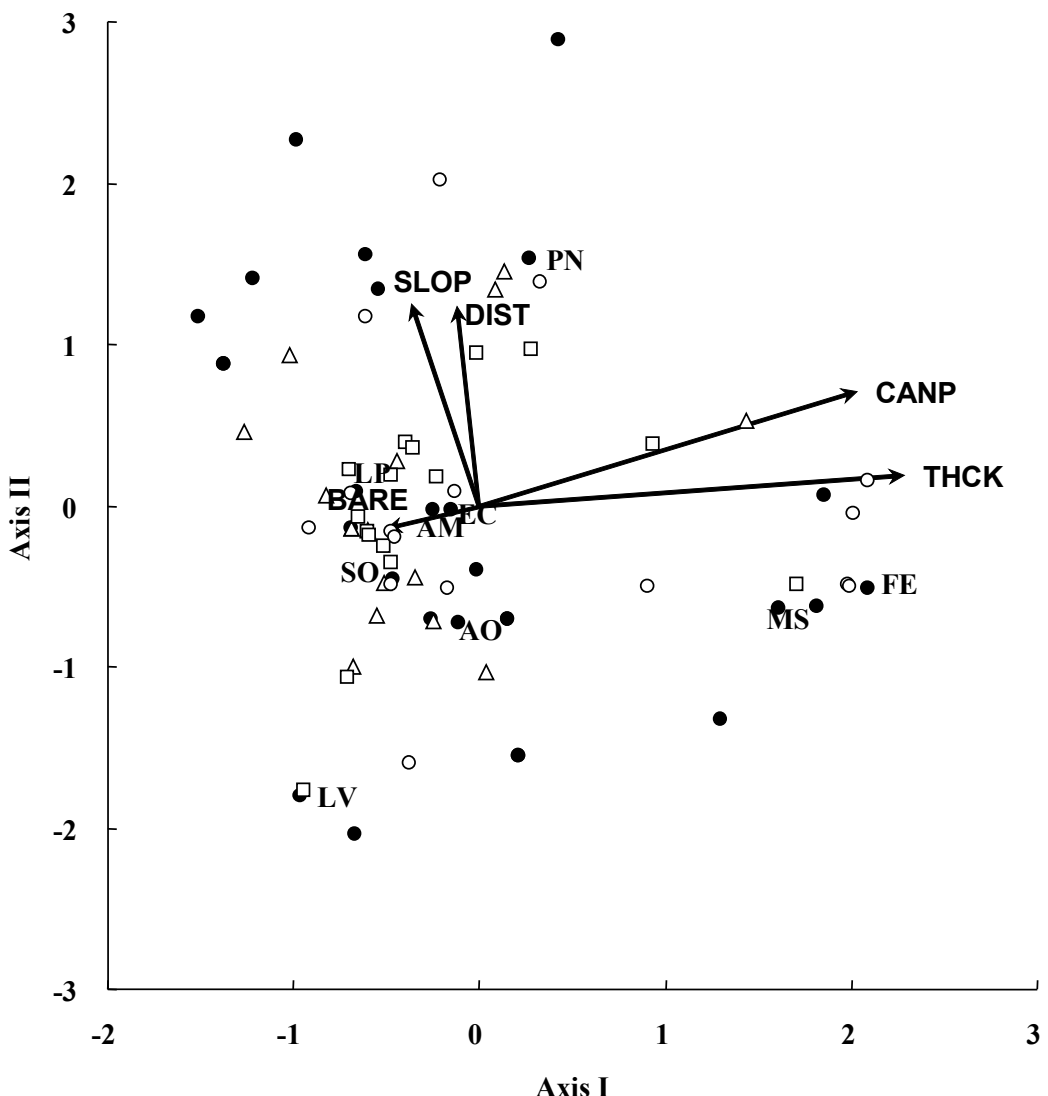

The first two axes of CCA explain $45.0 \%$ of species-environment relation (Fig. 1). Species-environmental correlations were 0.930 on axis I and 0.823 on axis II. Unconstrained Monte Carlo permutation tests showed that these results were significant at $\mathrm{P}<0.01$. Of the available environmental variables, litter thickness and canopy area were strongly related with axis I. Canopy area had a significant $t$-value on axis I $(t$ value $=3.79)$, but litter thickness was not significant (absolute $t$-values $=1.62$ ). This result suggested that the prime determinants on community patterns could be regarded as canopy area that was mostly occupied by Quercus garryana. Distance from the road is associated with axis II. The significance was confirmed by the high $t$-value (absolute $t$ value $=5.61$ ). Slope was not strongly related to any axes. The plot scores did not make any aggregative patterns in relation to cover category, and bare area was not a prime determinant on vegetation pattern.

Festuca elatior and Melica spectabilis Schribn. showed high values on the first axis, while the other species had low scores (Fig. 1). This implied that these two species established well on plots with high canopy cover and/or thick litter. However, the niche overlap between them was extremely low (Tab. 2). These results implied that $F$. elatior and $M$. spectabilis did not establish together but had similar habitat preference. Because species less than $20 \%$ appearance frequencies, including $F$. elatior and M. spectablis, showed low niche overlaps, probability that these infrequent species appeared in the same plots was low and thus niche overlaps became low. In contrast, Lepidium virginicum favored to establish on plots with low canopy cover and/or thin litter (Fig. 1). Poa nervosa established more on plots that were apart from road.

\section{Discussion}

The species composition did not change greatly along plot-cover gradient, and most species reasonably declined in cover and/or frequency with a decrease in plot cover. However, Sisymbrium officinale showed a specific establishment pattern along the gradient, i.e., this species increased in frequency with decreasing plot cover. Species being adaptive to disturbed environments, such as exotic species, are used as indicator species to evaluate environmental deterioration (Gibson \& Bosch 1996, GuerreroCampo \& Montserrat-Marti 2004). In particular, outdoor recreation represented by hiking and camping greatly affect the distributions of species and vegetation in mountainous regions (Pottio \& Beatty 2005). S. officinale could be an indicator for human impacts in roadside grassland vegetation in oak woodlands. An exotic species for Germany, Heracleum mantegazzianum utilizes roadsides for invasion (Thiele \& Otte 2008). Niche overlaps show that the three species $S$. officinale, Anthoxanthum odoratum and Achillea millefolium overlap highly in establishing sites, although the latter two species decrease in frequency with a decrease in plot cover. Those results suggested that the two species are more intolerant than $S$. officinale to land cover decrease.

The species richness is the highest in midcover plot, due to the abundance of exotic species. This pattern could be supported by intermediate disturbance hypothesis, in particular, for exotic species along forest roads (Watkins et al. 2003), and the further problem is the high species richness is maintained by exotics. When the highest species richness is observed in intermediately disturbed grassland in the mountainous regions of central Alberta, Canada, exotic species contribute greatly to the high species richness on more intensely disturbed areas than native species due to higher tolerance to human disturbances (Vujnovic et al. 2002). Those indicate that high species richness is not always desirable when exotic species modifies vegetation patterns.

An upper layer, such as canopy, can modify the lower layers, via various pathways. Even though tree canopy cover is low, it af- 
fects understory vegetation patterns by influencing sunlight and/or soil development (Oliver \& Larson 1996). Likewise, the patterns of human impacts, including trampling, on vegetation are associated with tree crown distribution patterns in forested recreational areas, because road network is designed based on topography and tree distribution (Simonds 1997). Trampling decreases the depths of soil and litter (Goudie 2005). Therefore, the distribution of tree canopy is likely to be a trigger that promotes various environmental changes, e.g., litter thickness, and trampling.

Distance from the road is related to the second axis, not to the first axis. This indicates that human impacts such as trampling are not always intense on roadsides in recreational areas and that distance from the road is a distinct factor from the factors related to the first axis, i.e., tree canopy cover. However, exotic species are common even far from the roadway in the oak forest (Thysell \& Carey 2001), showing that human impacts have an effect not only near roadside areas, in particular, in the recreational areas of mountain regions.

In conclusion, the prevention of tree density and distribution is of prime importance for the herbaceous vegetation development, because trees and forests control not only distribution patterns of soil and sunlight factors but also the patterns of human impacts, such as trampling. To change the pattern of human impacts, the arrangement of road network should be re-considered (Gelbard \& Belnap 2003). To conserve mountainous recreational areas, therefore, the layout of road networks, including mountain trails, should be mentioned carefully.

\section{References}

Colwell RK, Futuyma DJ (1971). On the measurement of niche breadth and overlap. Ecology 52: 567-576. - doi: 10.2307/1934144

Gelbard JL, Belnap J (2003). Roads as conduits for exotic plant invasions in a semiarid landscape. Conservation Biology 17: 420-432. - doi: 10.1046/j.1523-1739.2003.01408.x
Gibson RS, Bosch OJH (1996). Indicator species for the interpretation of vegetation condition in the St Bathans area, central Otago, New Zealand. New Zealand Journal of Ecology 20: 163-172. [online] URL: http://www.newzealandecology.org/nzje/free_issues/NZJEcol20_2_163.pdf Goudie A (2005). The human impact on the natural environment: past, present, and future $\left(6^{\text {th }}\right.$ edn). MIT Press, London, UK, pp. 376.

Guerrero-Campo J, Montserrat-Marti G (2004). Comparison of floristic changes on vegetation affected by different levels of soil erosion in Miocene clays and Eocene marls from Northeast Spain. Plant Ecology 173: 83-93. - doi: 10.1023/B:VEGE.0000026331.85303.c8

Labuz TA, Grunewald R (2007). Studies on vegetation cover of the youngest dunes of the Swina Gate Barrier (western Polish coast). Journal of Coastal Research 23: 160-172. - doi: 10.2112/030119.1

Leps J, Šmilauer P (2003). Multivariate analysis of ecological data using CANOCO. Cambridge University Press, Cambridge, UK

Moreno-de las Heras M, Merino-Martin L, Nicholau JM (2009). Effects of vegetation cover on the hydrology of reclaimed mining soils under Mediterranean-Continental climate. Catena 77 : 39-47. - doi: 10.1016/j.catena.2008.12.005

Myers JH, Bazely DR (2003). Ecology and control of introduced plants. Cambridge University Press, Cambridge, UK, pp. 328. - doi: 10.1017/CBO9780511606564

NCDC (1993). US station climatological summaries. National Climatic Data Center, Asheville, NC, USA.

Oliver CD, Larson BC (1996). Forest stand dynamics. McGraw-Hill Inc., New York, USA, pp. 544.

Pottio AP, Beatty SW (2005). Impacts of recreation trails on exotic and ruderal species distribution in grassland areas along the Colorado Front Range. Environmental Management 36: 230-236. - doi: 10.1007/s00267-003-0177-0

Rexroad EA, Beard KH, Kulmatiski A (2007). Vegetation responses to 35 and 55 years of native ungulate grazing in shrubsteppe communities. Western North American Naturalist 67: 16-25. doi: 10.3398/1527-0904(2007)67[16:VRTAYO] 2.0. $\mathrm{CO} ; 2$
Riegel GM, Smith BG, Franklin JF (1992). Foothill oak woodlands of the Interior Valleys of Southwestern Oregon. Northwest Science 66: 6676.

Sauer T, Ries JB (2008). Vegetation cover and geomorphodynamics on abandoned field in the Central Ebro Basin (Spain). Geomorphology 102: 267-277. - doi: 10.1016/j.geomorph. 2008.05.006

Simonds JO (1997). Landscape architecture: a manual of site planning and design. McGrawHill, Inc., New York, USA pp. 352.

Thiele J, Otte A (2008). Invasion patterns of Heracleum mantegazzianum in Germany on the regional and landscape scales. Journal for Nature Conservation 16: 61-71. - doi: 10.1016 j.jnc.2007.08.002

Thilenius JF (1968). The Quercus garryana forests of the Willamette Valley, Oregon. Ecology 49: 1124-1133. - doi: 10.2307/1934496

Thysell DR, Carey AB (2001). Quercus garryana communities in the Puget Trough, Washington. Northwest Science 75: 219-235.

Trombulak S, Frissell C (2000). Review of ecological effects of roads on terrestrial and aquatic communities. Conservation Biology 14: 18-30. doi: 10.1046/j.1523-1739.2000.99084.x

Turton SM (2005). Managing environmental impacts of recreation and tourism in rainforests of the wet tropics of Queensland World Heritage Area. Geographical Research 43: 140-151. - doi: 10.1111/j.1745-5871.2005.00309.x

Vujnovic K, Wein RW, Dale MRT (2002). Predicting plant species diversity in response to disturbance magnitude in grassland remnants of central Alberta. Canadian Journal of Botany 80: 504-511. - doi: 10.1139/b02-032

Walker LR, Chapin III FS (1987). Interactions among processes controlling successional change. Oikos 50: 131-135. - doi: 10.2307 3565409

Watkins RZ, Chen J, Pickens J, Brosofske KD (2003). Effects of forest roads on understory plants in a managed hardwood landscape. Conservation Biology 17: 411-419. - doi: 10.1046/j.1523-1739.2003.01285.x

Zar JH (1999). Biostatistical analysis. PrenticeHall, Englewood Cliffs, NJ, USA, pp. 931. 